\title{
Feeling like a student but thinking like a teacher: a study of the development of professional identity in initial teacher education
}

\author{
Maria Assunção Flores \\ Institute of Education, University of Minho, Braga, Portugal
}

\begin{abstract}
This paper draws upon a wider piece of research aimed at investigating professional identity development in initial teacher education. It is based upon the view of identity as a dynamic and multifaceted process and initial teacher education as a key context for its development. Data reported in this paper are part of a broader project carried out in Portugal and was collected through written narratives with 20 student teachers. In this paper findings arising from student teachers' accounts are presented, according to the main emerging themes: i) feeling like a student and thinking like a teacher; ii) confronting present and past experiences: inner tensions and dilemmas; iii) raising awareness of the complexity of the classroom context; iv) the teaching profession: aspirations and concerns of prospective teachers. Implications of the findings for initial teacher education are discussed.
\end{abstract}

\section{KEYWORDS}

Initial teacher education; identity; student teachers

\section{Introduction}

The study of teacher identity has expanded over the last two decades or so. It has been considered as an organising element in teachers' development as professionals focusing on their beliefs, actions, influences and contexts of training and workplace (Beijaard, Verloop, and Vermunt 2000; Flores and Day 2006; Thomas and Beauchamp 2011; Sutherland, Howard, and Markauskaite 2010; Zimmermann, Flavier, and Méard 2012; Flores 2006, 2013).

The transition from student to teacher and the early years in teaching have received a great deal of attention over the last decades (Flores 2001; Flores and Day 2006; Pillen, Beijaard, and den Brok 2013; Thomas and Beauchamp 2011, 2007; Hong 2010; Smagorinsky et al. 2004; Yuan and Lee 2016; Carrillo and Flores 2018). Earlier research pointed to the multi-dimensional process of teacher identity development which is influenced by personal, social and cognitive response, as it implies an 'ongoing and dynamic process which entails the making sense and (re)interpretation of one's own values and experiences' (Flores and Day 2006, 220).

More recently, a growing body of literature has highlighted the key role of initial teacher education (ITE) as a crucial context for developing teacher identity (Beauchamp and Thomas 2009; Timostsuk and Ugaste 2010; Schepens, Aelterman, and Vlerick 2009; Flores 2011; 
Nickel and Zimmer 2018) but it also acknowledges the scarcity of research in this area (Beauchamp and Thomas 2009; Schepens, Aelterman, and Vlerick 2009; Zimmermann, Flavier, and Méard 2012). Beauchamp and Thomas $(2009,186)$ stress that teacher education programmes seem to be 'the ideal starting point for instilling not only an awareness of the need to develop an identity, but also a strong sense of the ongoing shifts that will occur in that identity'. Additionally, Beijaard $(2019,3)$ discusses the process of learning to teach as an identity making process in which he stresses that 'learning or developing a teacher identity is imbued with and fuelled by many aspects that are primarily personal, such as one's own biography, aspirations, learning history, and beliefs about education' including 'the hopes, dreams, and ideals that students bring with them to teacher education'.

Existing literature has highlighted the dynamic, complex, ongoing and shifting nature of teachers' professional identity. It has been associated with given views of how teachers see themselves as teachers including elements related to self-efficacy, motivation, pedagogical views, perspectives on relationships with pupils and colleagues; emotions; commitment; professional values, and beliefs about teaching and learning and about being a teacher (Flores and Day 2006; Lamote and Engels 2010; Beijaard, Meijer, and Verloop 2004; Timostsuk and Ugaste 2010; Schepens, Aelterman, and Vlerick 2009; Pillen, Beijaard, and den Brok 2013; Nickel and Zimmer 2018). The purpose of this study is to investigate the development of student teachers' professional identities during ITE taking a longitudinal perspective. Two cohorts of student teachers who were enrolled on a Master's degree in teaching were followed during a two-year period. The wider study focuses on student teachers' beliefs about teaching and becoming a teacher, their professional values as teachers-to-be and their views of teaching as well as their experiences in ITE and the ways in which they make sense of them. In this paper, data collected at the end of the first semester in year 1 will be reported.

\section{ITE and the formation of teacher professional identity}

Learning to teach is a process that goes beyond the mere application of a set of acquired techniques and skills. Not only does it imply the mastery of practical and more technical issues, but it also encompasses the construction of knowledge and meaning in an ongoing dialogue with the practice (Flores 2001, 146). Thus, a sense of professional identity becomes crucial if the process of becoming a teacher is to be fully understood. In their review of research on teachers' professional identity, Beijaard, Meijer, and Verloop (2004) identified four characteristics of identity: i) it is not a fixed or stable entity, rather it is a dynamic process involving the (re)interpretation of experiences; ii) it entails the interaction between the person and the context; iii) it consists of a set of sub-identities that more or less harmonise; and iv) it implies teacher agency.

In a similar vein, Sachs (2001) describes identity as a negotiated, open and shifting process. This interactive and dynamic view of identity is also stressed by Beijaard, Meijer, and Verloop (2004) and Pillen, Beijaard, and den Brok (2013) as they highlight the personal and the professional dimensions and the idea of an ongoing negotiation and reflection about oneself as a teacher in a given context in which identities are (re)shaped. Developing teacher identity entails, therefore, a process of integrating one's personal knowledge, beliefs, attitudes, norms and values and the professional demands within teacher education institutions and schools (Beijaard, Meijer, and Verloop 2004). 
Existing literature has drawn attention to the need to focus on the identity development during ITE (Timostsuk and Ugaste 2010; Schepens, Aelterman, and Vlerick 2009; Lu and Curwood 2015). For instance, Schepens, Aelterman, and Vlerick (2009), in their study of the tension between being born as a teacher (focusing on demographics and personality traits) and becoming a teacher (based on experience), concluded that ITE is a key context in professional identity formation along with issues related to demographics, personality traits and experience. Similarly, Sancho et al. (2014), in research carried out in Spain, analysed the influence of issues such as 'becoming a teacher' and 'being a teacher'; beliefs about childhood dream of vocation versus discovery and commitment; and the key relevance of building caring relationships with the students. They make the case that it is essential to investigate more deeply teacher professional identity in ITE which is seen as a 'process of self-construction woven from ongoing interactions with other individuals - each one with their biological, biographical and social backpack - educational policies, colleagues, power structures and power relations found in schools, students and families' (2014, page, 19) (original emphasis).

Timostsuk and Ugaste (2010) focused on the emotions of 45 student teachers in Estonia and found that negative emotions exercised the strongest influence on their professional identity. They also concluded that supervisors neglected the role of positive emotions as a support for learning and that the most positive emotions were associated with situations involving students. The authors argue for the role of emotions in developing student teachers' identity and the need to look at and discuss their expectations in greater detail. In a similar Flores (2014a), Flores (2014b)) stressed the importance of developing pedagogies that support the development of student teachers' identity, particularly in the context of ITE, namely through the examination of both its formal and informal curriculum, the explicit pedagogies of teaching how to teach and how to learn and develop as a teacher.

The role of the context of teacher education in the formation of identity has been stressed in research literature although evidence is still scarce (Schepens, Aelterman, and Vlerick 2009; Zimmermann, Flavier, and Méard 2012). As Zimmermann, Flavier, and Méard (2012) state, student teachers are confronted with the need to make sense of different aspects of their role as teachers, namely the school as an institution, the children and young people as students; teachers' work with its responsibilities, colleagues, and students' parents. As such, ITE should provide student teachers with guidance and support on how to 'become' good teachers involving the personal and professional change rather than in 'knowing' about teaching (Schepens, Aelterman, and Vlerick 2009). This paper aims to add to existing literature on the development of teacher professional identity in ITE, taking into account student teachers' beliefs, views and experiences and the ways in which they make sense of them during a two-year Master's degree in teaching.

\section{The study}

\section{The context}

Portugal has undergone a restructuring process of ITE programmes as a result of the implementation of the Bologna Process. Existing legal framework draws on the DecreeLaw $n^{\circ} 43 / 2007$, which stipulates the professional qualifications for teaching (from preschool to secondary education). In order to become a teacher, a three-year degree is needed, plus a master's degree in teaching (a two-year programme). It implies, therefore, the 
separation between training in the first cycle (three-year programme called licenciatura) and training at second cycle level (master's degree, which is now needed in order to enter the teaching profession from pre-school to secondary education). As such, a consecutive model was introduced replacing the 4 to 5 year undergraduate teaching degrees before the implementation of the Bologna process. These undergraduate degrees were of two types: i) five-year integrated programmes which included 4 years of full-time study at university in which student teachers would benefit from education in educational sciences and subject matter simultaneously from the very beginning of the programme plus one year of practicum in a school; ii) sequential programmes where students did their education to become teachers for one or two years, after completing three years of subject-related education.

The most recent changes point to an increase of subject knowledge and didactics along with longer programmes at Master's level (Decree-Law no 79/2014). ITE curriculum includes: i) training in the subject matter; ii) general educational training; iii) specific didactics (for a given level of teaching and subject matter); iv) cultural, social and ethical education, and v) professional practice. This new configuration, within the context of a consecutive model, has been seen as a drawback in relation to previous models of teacher education. The new model emphasises the subject knowledge and didactics, and the professional practice occurs mainly at universities, which implies less time in schools (Flores 2016, 2018; Flores, Vieira, and Ferreira 2014; Flores et al. 2016). Issues such as the separation of subject knowledge and pedagogy, and the fragmentation of the curriculum components have also been identified (see, Flores 2011; Flores, Vieira, and Ferreira 2014; Flores et al. 2016; Vieira, Flores, Silva and Almeida, 2019). As Moreira and Vieira $(2012,97)$ stated, 'the impact of this structural change is not yet clear; will second-cycle student teachers take teaching more seriously because they had more time to decide to become teachers, or will they take it less seriously because their training is shorter? And will they be able to integrate subject and pedagogical knowledge now that these curricular components are clearly separated?' (reference and page number).

Along with changes in the curriculum of ITE, it is important to take into account the broader social, political and economic context in which it is situated. Over recent years in Portugal, teacher surplus and unemployment became two intertwined realities with implications for the recruitment of student teachers in higher education institutions and for new teachers' job expectations. A financial and economic crisis, leading to salary cuts and higher taxes, has affected Portuguese society at various levels, including the teaching profession, with high rates of unemployment, especially for qualified young people. This situation has implications for student teachers' motivations and expectations for entering a teaching degree and the teaching profession.

\section{Goals, methods and participants}

Data reported in this paper draw upon a longitudinal research project aimed at investigating the process of professional identity development in the context of ITE (a two-year Master's degree in teaching). This paper addresses the following research questions: How do student teachers see themselves as teachers-to-be? What kinds of activities and experiences in ITE context influence their journey to become teachers? Do they change their beliefs related to becoming and being a teacher? Why? Why not? 
Student teachers enrolled in ITE were invited to participate in the project and 20 of them volunteered. All of them were enrolled in a Master's degree in teaching in their first year first semester of the programme. In this paper data are drawn from 20 student teachers enrolled in their first semester in a Master's degree in Teaching Philosophy and a Master degree in Portuguese and Spanish. Their age ranged from 22 to 28 years of age, and 19 of the participants were female. Student teachers were asked to write about their experience of learning to teach throughout semester 1 year 1 in their Master's degree programme. They were asked to identify the most relevant learning experiences as well as the ways in which they have influenced their views of the teaching profession and of being a teacher. Ethical considerations according to international practice in educational research were taken into account namely informed consent, confidentiality of the data, participants' rights, and access to the data and its dissemination. Only the researcher had access to the narratives. All references to places, people and institutions were removed before the final analysis. All student teachers signed a voluntary informed consent form. In the dissemination of the data pseudonyms were used.

In this paper, data collected through written narratives at the end of the first semester of the 2-year Master's degree are presented. Written narratives provide a great deal of potential in raising awareness and reflecting on beliefs, implicit theories and life histories and making sense of one's own experience (Elliott 2005). People are invited to identify and reflect about specific moments or situations and learning from them through a process of meaning making (Elliott 2005), taking into account time and space and the social context (Clandinin, Pushor, and Orr 2007).

Data analysis was undertaken according to two phases: a vertical analysis (Miles and Huberman 1994) according to which each of the respondents' accounts was analysed separately. A second phase was then carried out according to a comparative or horizontal analysis (cross-case analysis) (Miles and Huberman 1994). In this phase, the method of 'constant comparative analysis' (Glaser and Strauss 1967) was used to look for common similarities as well as differences. Key themes and categories arising from the narratives were identified and then summarised and labelled accordingly. The categories were obtained through an iterative process that included coding, recoding and verification of final key themes and categories prior to the final analysis of the data. To ensure relevance and trustworthiness of the findings final themes and categories as well as quotes from the participants were discussed with colleagues.

\section{Findings}

In this section findings arising from student teachers' accounts are presented, according to the main emerging themes: i) feeling like a student and thinking like a teacher; ii) confronting present and past experiences: inner tensions and dilemmas; iii) raising awareness of the complexity of the classroom context; iv) the teaching profession: aspirations and concerns of prospective teachers.

\section{Feeling like a student but thinking like a teacher}

Student teachers depicted the ways in which they managed the tension between feeling like a student but having to think like a teacher. For instance, the participants' accounts 
highlighted the importance of engaging in pedagogical activities in the classroom in their process of learning to teach, such as writing and analysing narratives about their motivations and expectations for becoming teachers; participating in debates about student assessment, developing peer activities about teaching and school curriculum; writing narratives about 'my most remarkable teacher'; listening to students' voices about their teachers drawing from existing research literature; and reading and exploring letters from (fictional) teachers pointing to different ways of being a teacher and of looking at teaching as a profession. Through these activities, they were provided with opportunities to explore their beliefs and implicit theories about being a teacher making their own professional values as teachers-to-be more explicit. Most of the participants stressed their own experiences as students and the ways in which they had made sense of them by rethinking and revisiting, in some cases, their implicit values and beliefs:

As a student, when I had to sit for a written test, I had many times thought, "oh, if I just could tell the teacher that I don't feel like doing the test". But then, I thought "this doesn't matter to the teacher". And then I couldn't ever realise that as a student teacher I would be discussing in the classroom about assessment, about the kinds of factors that influence assessment and so on ... this was a really discovery for me as a teacher-to-be. (Maria)

I feel that now I am a different person. I felt I had made important learning experiences because it was possible for me to become more aware about what kind of student I am and what kind of teacher I would like to be. (Karen)

It was clear that student teachers' expectations and beliefs about be(com)ing a teacher were challenged in ways that made them revisit their past experiences as students and put into a different perspective their current learning experiences in ITE as they became more aware of the complexity of teaching and learning to teach.

\section{Confronting present and past experiences: inner tensions and dilemmas}

Past and present experiences of student teachers were described in detail in the narratives. They entail the inner tensions and challenges related to their role as students but at the same to their future role as teachers. Student teachers reported that they have challenged their beliefs about teaching and about being a teacher towards a stronger focus on pupils. The experience of analysing in more detail the process of teaching and learning from the inside through the lens of both student and teacher-to-be has led them to question some of their ideas and beliefs. Through learning and, more importantly, through analysing their learning experiences in the classroom, both individually and collectively, it was possible to enhance the pedagogical voice and to stimulate productive learning in ITE (Russell and Martin 2014). The participants reported that they have moved beyond their taken-for-granted ideas about teaching.

I am more concerned with the students than I was before, I believe in assessment as learning. I guess I was able to experience a lived example of assessment as learning as student teacher, namely the techniques for assessment that were used, the modes of assessment, the guidelines, etc. I believe that I cannot be a good teacher if I am not able to assess my students in a fair and adequate way.(Mia)

In the process of challenging and changing their views of teaching, the participants have made sense of their own process of becoming a teacher. Some of the issues were 
critical in this regard, namely the debates and reflection about teacher autonomy and the legal framework of teaching. These have made them more aware of the potential but also of the constraints of the teaching profession. Discovering this reality through reading accounts of practising teachers were of paramount importance in the process of constructing, reconstructing and deconstructing their own ways of being and feeling like a teacher. The most striking features were bureaucracy in teaching, control over teachers' work from a legal and curricular point of view (i.e., national exams, national curricula, top-down model of decision making, etc.), along with the intensification of teachers' work.

For me the most striking experience was the ways in which teaching is actually seen. I wasn't prepared to enter and to live in the "world of being a teacher" at all. I had no clue about what it implies to be a teacher in a Portuguese school nowadays with all the policy initiatives that are going on ... (Emma)

I became aware of the amount of paperwork that teachers have to deal with. This "imposed" bureaucracy is not good to the profession and I feel that no matter how good my intentions are as a future teacher, the conditions for teaching will determine the degree of autonomy that I may or may not exert. (Karen)

\section{Raising awareness of the complexity of the classroom context}

Most of the student teachers stressed the ways in which their participation in debates in the classroom became a key moment for their professional learning because they had the opportunity to talk about their points of view. Some of them claimed that they reinforced their own beliefs, for instance, of the importance of formative assessment and teacher autonomy; others, on the contrary, started to question teachers' autonomy in practice. Others claimed that they have revisited their rather simplistic and narrow views of the role of the teacher in curriculum development. Issues of the complexity and dynamic nature of teaching were at the forefront of their accounts:

My colleagues and I were able to discuss and reflect together on key issues of our work as future teachers. I have learned a lot through inquiry and debating my ideas with my colleagues. (...) Teaching is much more complex than I was expecting. It depends on how you see yourself as a teacher, for instance, the ways you look at your role in the classroom or in developing the school curriculum. (Maria)

As a future teacher I have realised that, in a way, my work as a teacher is very much determined by the legal framework but I also realised that in the classroom I may have autonomy to work with my students the way I want. I may be flexible, creative and promoting student interaction in the classroom ... (Emma)

Listening to practicing teachers' voices and discussing them in the classroom with my colleagues was a discovery process and a way of unpacking my own hidden or implicit views of being a teacher. I became more and more aware of the dos and don'ts of curriculum decisions in the school. (Alexia)

Although some of them were aware of the most recent changes in teaching and teachers' work in the Portuguese context, related to a great extent to the financial and economic crisis, through the media and through relatives who were also teachers, others still held the idealistic view of being a teacher which was associated with a sense of vocation and 
a sense of purpose for their teaching in order to contribute to the development of their students as active citizens:

I have learned that despite the demanding and more and more complex nature of teachers' work, due to the government initiatives that focus on an outcome-driven perspective, as a teacher you can make a difference. You need to comply with bureaucracy but you need to think that students are people, not figures, so you need to support them in their learning. I have understood that teaching has also a political dimension ... (Sarah)

I have been given the opportunity to become aware of issues of teaching and being a teacher that disturb me a lot and that make me think about the teaching profession. I think that recent curricular and organisational policy directives have been negative and are having negative effects on schools and teachers' work. My vision is not positive at all, but I still believe that it is worth making an effort to make a difference in my students' lives. (Martha)

Although some student teachers had an idea about the challenges and demands placed upon teachers and schools, which were associated with the bulk of policy initiatives over the last few years, they recognised that they had the opportunity to frame and understand their implications for schools and teachers' work. Changes related to school curriculum towards a 'back to basics' logic, with an emphasis on content knowledge and the reinforcement of subjects such as mathematics and Portuguese, the introduction of national exams, teacher evaluation, etc. are but few examples of the policy initiatives with an impact on student teachers' views about the teaching profession. However, many of them still believe that they want to try to make a difference as teachers, despite the difficulties and challenges:

My experience was of great relevance particularly because it made me rethink my prior views of teaching and being a teacher. (...) The idea that I had about school curriculum at the beginning has been changed towards a more complex and context-dependent one. But I also realised that teachers' work is more and more top-down controlled. (Susan)

Having a clear vision about teaching and about education in general, being able to clarify and make professional values as teachers explicit, developing and communicating a sense of purpose for teaching were recurrent elements in student teachers' accounts. This was possible through the opportunities to look back on their own experiences as school students and to revisit their own experiences as well as to look forward in imagining the kinds of teachers they wanted to become.

I had the opportunity to look back on my own experience as a student at school and I feel that being reliable and clear is a key issue in developing your work as a teacher. This wasn't my experience as a student in many cases and I now feel that as a teacher-to-be I need to have clear professional values and to communicate them to my students through my action and attitudes as a teacher in the classroom. I guess many teachers forget that they were students in the past and they do not understand students' points of view. It was really insightful the way we discussed our own experience as students and our own values as future teachers. (Diane).

As this last quotation illustrates, the participants were able to question their own views of teaching and being a teacher and to revisit their experiences as students. They highlighted the tensions and contradictions between discourse and reality and between a student and a teacher perspective. Issues such as coherence and consistency of professional values and beliefs and practices were at the forefront of their accounts. 
I have revisited my idea of what being a teacher entails. It is a much more complex and dynamic process than I thought it would be. The challenges are great and you need to stick to what you believe as a teacher, in other words, your professional values and principles ... (Amanda)

\section{The teaching profession: aspirations and concerns of prospective teachers}

Student teachers held a rather negative view about teaching as a future career. The lack of job prospects, the non-existence of a teaching career, the high rate of unemployment in teaching which has been exacerbated in recent years with the financial and economic crisis etc., were recurring concerns.

Many times I think about teaching as my future career and about what I have to go through to get there. What am I going to find? I guess I will find a jungle out there. You will need to do whatever to find a place ... (...) it was a surprise for me but at the same time a disappointment that as a teacher your job is very difficult and that there are matters that go beyond what a teacher should do, for instance, paperwork and administrative tasks which keep you away from your work directly with students and this is for me central to teaching. The second point that I would like to make is that this disappointment has made me better prepared to face what is expected of me as a future teacher and maybe I can better contribute to a better teaching. (Martha)

The participants also reported that they were able to discuss the challenges they will have to face as future teachers as they were able to analyse the shortcomings of recent policy in education, they were able to go a step further in reflecting on teaching as a profession and on the teachers' role. If some of them were sceptical about teaching as a profession, many of them remained positive and talked about hope in teaching:

I feel quite anxious about the future of the teaching profession, the future of schools and the future of children and young people ... If I manage to be a teacher one day - the situation is very dark at the moment in terms of job prospects - I will try to do my best and to make a difference to my students. (Alexia)

In their accounts, student teachers also talked about their aspirations about being a teacher in the future. They have made the decision to enter a teaching degree and to become teachers in challenging times. Most of them mentioned the adverse times that the teaching profession has been through over recent years amongst which are the deterioration of the social image of teachers, and particularly the role of the media in disseminating negative features about schools and teachers, the bureaucratisation of teachers' work and, of course, the lack of career prospects, the salary cuts and the high rate of unemployment in teaching. This picture is well documented in recent research carried out in Portugal (Flores 2014c) and in Spain (Sancho et al. 2014) with implications for teacher education and the development of the teaching profession, but experiences of resilience were also found. The interaction with students and the positive relationships with colleagues at school were seen as sources of personal and professional motivation against the odds (Flores, Ferreira, and Parente 2014).

The participants revealed mixed feelings about their aspirations as teachers. On the one hand, scepticism and lack of motivation emerged; on the other hand issues of hope and self-confidence marked their reflections about being a teacher in the future. In other words, despite the perceived 'darkness' and the 'insecurity' of teaching as profession, they 
stressed that they would like to get to schools and to classrooms and tryingto give their best as teachers for the benefit of their students:

My pathway to become a teacher may be dangerous and stormy, but I won't give up without trying to get there. I am aware that escalating for a mountain is not easy when you don't know your way. I know what is expecting from me and I will try to do my best ... (Caroline)

I was able to clarify my own ideas about what kind of teacher I want to become. It helped me to remember the good and bad teachers that I meet as a student and to rethink the dos and don'ts of a teacher. I feel more prepared to do my practicum and to enter the classroom. But I am also aware that the journey to becoming a good teacher is long and complex ... I also know that as a teacher I want to try to make the dreams of my students come true (Julia)

Issues about what kinds of teachers they will be, about what kinds of teachers they want to be, and about the difference they will make in their contexts of working are examples of the reflective questions in their final accounts. If some of them are unsure about the answers to these questions, others seemed to be more consistent about what kind of teacher they want to be and about the experiences they want to provide for their students.

As a future teacher I feel more able to identify my mistakes as a teacher. I am aware that my job is complex and that I will be making mistakes but I also know that I can identify them and overcome them and get better and better. (John)

I've always wanted to become a teacher. It was a dream and in my dream, I wanted to be the best teacher I could. I had the possibility to reflect on my own experience as a student and this was great as I was able to clarify my own values as a teacher-to-be. (Sophie)

\section{Discussion and conclusions}

This paper draws on data from written narratives and illustrates the key themes of student teachers' reflections on their journeys to becoming teachers. Through their own voices, it was possible to explore the main issues that contributed to making the transition from student to teacher and to analysing aspects of the formation of their professional identity. Their motivations and influences to enter a teaching degree and to become teachers in a context in which the teaching profession is facing adverse times were analysed with implications for understanding the role of intrinsic and extrinsic motivations and issues of student teachers' recruitment (Flores and Niklasson 2014).

The opportunities for making student teachers' beliefs more explicit and for revisiting their own experiences as students as well as discussing their role by clarifying their sense of purpose for being a teacher were highlighted in their accounts. Of particular relevance were the pedagogical activities they engaged in, namely writing and analysing narratives about their motivations and expectations for becoming teachers; participating in debates; developing peer activities about teaching and school curriculum; and reading and exploring letters from (fictional) teachers pointing to different ways of being a teacher and of looking at teaching as a profession.

Making explicit their implicit theories was not an easy job for them, especially when they were confronted with the demanding and complex nature of teaching in adverse circumstances. Idealism versus scepticism and negativism versus hope were recurring elements in their accounts. The idealistic view of being a teacher clashed with the reality 
of unemployment, the lack of valorisation of the teaching profession and all recent policy initiatives implemented over the last few years under the austerity measures. However, if the dark reality and the lack of professional prospects were acknowledged by the participants, they also stressed their sense of vocation and the personal choice of being a teacher. They have challenged their own beliefs and aspirations influencing teacher identity development seen as a non-linear process marked by contradictions, tensions and doubts (Zimmermann, Flavier, and Méard 2012). They were able to revisit their views and experiences as school students but at the same time to challenge their initial beliefs about teaching and about being a teacher. Their views of becoming a teacher were constructed, deconstructed and reconstructed as they made the transition from a student's towards a teacher's perspective.

The (trans)formation of professional identity is influenced by beliefs and expectations about what a teacher should be able to know and do (Beijaard, Meijer, and Verloop 2004). As Beauchamp and Thomas $(2009,178)$ argue, 'teacher identity is shaped and reshaped in interaction with others in a professional context'. Thus, it is crucial to develop and evaluate pedagogies in initial teacher education that are supportive of professional learning of how to become and be a teacher in a given social, cultural and economic context. Ben-Peretz and Flores (2018) identify the competing expectations of the meaning of teacher education in a context marked by tensions and contradictions, for instance, preparing for professional autonomy in a world of externally imposed educational policy, and achieving immediate results and success in external exams versus the need to prepare students in an era of migration and growing multiculturalism in school contexts.

This study adds to existing research that has found that most tensions in teacher identity development occur after teaching practice, namely between personal and professional aspects (Anspal, Leijen, and Löfström 2019). In research in Canada, Nickel and Zimmer (2018) also concluded that during practicum student teachers were able to realise the ideals articulated in their teaching philosophies, including a strong focus on student engagement and that their self-efficacy grew as they developed a sense of purpose in teaching. The study reported in this paper suggests that from the very beginning of the ITE programme student teachers were able to revisit their experiences as students, to make their views of teaching and being a teacher more explicit and to negotiate their role(s) as they start to make sense of their learning experiences as student teachers. Their journey to becoming teachers was marked by tensions, contradictions, aspirations and hopes which were clearly illustrated by the notion of 'feeling like a student but thinking like a teacher'.

While this study has limitations, due to the number of participants and to the choice of methods, it does show how student teachers look at present and past experiences and deal with inner tensions, contradictions and dilemmas even before entering the school and classroom context during practicum. The participants spoke of the ways in which they looked back on their experience as school students but also they made sense of their current situation as student teachers leading to the emergence of dilemmas and tensions related to the choice of the profession but also to their views of being a teacher. This is particularly relevant in a context that entails a great many challenges for preservice teachers associated with the lack of job prospects and to the deterioration of the socioeconomic status of the teaching profession. Giving voice to student teachers to challenge their own beliefs and experiences and to integrate in a more consistent way both the formal and implicit curriculum of ITE may well contribute to the development of teacher 
identity in a more explicit and meaningful way. As such, the enactment of explicit pedagogies for the development of professional identity becomes a key issue in ITE with implications not only for the design of the programmes, but also the role and practices of teacher educators.

\section{Disclosure statement}

No potential conflict of interest was reported by the author.

\section{References}

Anspal, T., A. Leijen, and E. Löfström. 2019. "Role in Student Teacher Identity Development in Primary and Subject Teacher Curricula." Scandinavian Journal of Educational Research. 63 (5): 679-695. doi:10.1080/00313831.2017.1420688.

Beauchamp, C., and L. Thomas. 2009. "Preparing Prospective Teachers for a Context of Change: Reconsidering the Role of Teacher Education in the Development of Identity." Cambridge Journal of Education 39 (2): 175-189. doi:10.1080/03057640902902252.

Beijaard, D. 2019. "Teacher Learning as Identity Learning: Models, Practices, and Topics." Teachers and Teaching Theory and Practice 25 (1): 1-6. doi:10.1080/13540602.2019.1542871.

Beijaard, D., N. Verloop, and J. D. Vermunt. 2000. "Teachers' Perceptions of Professional Identity: An Exploratory Study from a Personal Knowledge Perspective." Teaching and Teacher Education 16: 749-764. doi:10.1016/S0742-051X(00)00023-8.

Beijaard, D., P. C. Meijer, and N. Verloop. 2004. "Reconsidering Research on Teachers' Professional Identity." Teaching and Teacher Education 20: 107-128. doi:10.1016/j.tate.2003.07.001.

Ben-Peretz, M., and M. A. Flores. 2018. "Tensions and Paradoxes in Teaching: Implications for Teacher Education." European Journal of Teacher Education 41 (2): 202-213. doi:10.1080/ 02619768.2018 .1431216$.

Carrillo, C., and M. A. Flores. 2018. "Veteran Teachers' Identity: What Does the Research Literature Tell Us?" Cambridge Journal of Education. doi:10.1080/0305764X.2017.1394982.

Clandinin, D. J., D. Pushor, and A. M. Orr. 2007. "Navigating Sites for Narrative Inquiry." Journal of Teacher Education 58 (1): 21-35. doi:10.1177/0022487106296218.

Elliott, J. 2005. Using Narrative in Social Research.Qualitative and Quantitative Approaches. London: Sage.

Flores, M. A. 2001. "Person and Context in Becoming a New Teacher." Journal of Education for Teaching 27 (2): 135-148. doi:10.1080/02607470120067882.

Flores, M. A. 2006. "Being a Novice Teacher in Two Different Settings: Struggles, Continuities, and Discontinuities." Teachers College Record 108 (10): 2021-2052. doi:10.1111/tcre.2006.108.issue-10.

Flores, M. A. 2011. "Curriculum of Initial Teacher Education in Portugal: New Contexts, Old Problems." Journal of Education for Teaching 37 (4): 461-470. doi:10.1080/ 02607476.2011.611015.

Flores, M. A. 2013. "Be(com)ing a Teacher in Challenging Circumstances: Sustaining Commitment or Giving up in Portugal?" In From Teacher Thinking to Teachers and Teaching: The Evolution of a Research Community, edited by C. Craig, P. Meijer, and J. Broekemans, 359-385. New York: Emerald Publishers.

Flores, M. A., F. I. Ferreira, and C. Parente. 2014. "Conclusões E Recomendações." In Profissionalismo E Liderança Dos Professores, edited by M. A. Flores, 217-236. Santo Tirso: De Facto Editores.

Flores, M. A., F. Vieira, and F. I. Ferreira. 2014. "Formação Inicial De Professores Em Portugal: Problemas, Desafios E O Lugar Da Prática Nos Mestrados Em Ensino pós-Bolonha." In A Formação Inicial De Professores: Olhares E Perspectivas Nacionais E Internacionais, edited by M. C. Borges and O. F. Aquino, 61-96. Uberlândia: EDUFU. ISBN: 978-85-7078-373-1.

Flores, M. A. 2014a. "Teacher Learning in the Workplace in Pre-service Teacher Education in Portugal: Potential and Limits from a Pre-service Teacher Perspective." In Workplace Learning in Teacher 
Education. International Practice and Policy, edited by O. McNamara, J. Murray, and M. Jones, 243-260. Dordrecht: Springer.

Flores, M. A. 2014b. "The Development of Teacher Professional Identity: Influencing Contexts and Inner Tensions." In Aprender a ser docente en un mundo en cambio. Simposio internacional, edited by J. Sancho, J. Correa, X. Giró, and L. Fraga, 45-55. Barcelona: Dipòsit Digital de la Universitat de Barcelona.

Flores, M. A. 2014c. Profissionalismo E Liderança Dos Professores. Santo Tirso: De Facto Editores.

Flores, M. A., F. Vieira, J. L. Silva, and J. Almeida. 2016. "Integrating Research into the Practicum: Inquiring into Inquiry-based Professional Development in post-Bologna Initial Teacher Education in Portugal." In Redefining Teacher Education for the Post-2015 Era: Global Challenges and Best Practice, edited by M. A. Flores and T. Al-Barwani, 109-124. New York: Nova Science Publisher.

Flores, M. A. 2016. "Teacher Education Curriculum." In International Handbook of Teacher Education, edited by J. Loughran and M. L. Hamilton, 187-230. Dordrecht: Springer Press.

Flores, M. A. 2018. "Linking Teaching and Research in Initial Teacher Education: Knowledge Mobilisation and Research-informed Practice." Journal of Education for Teaching 44 (5): 621-636. doi:10.1080/02607476.2018.1516351.

Flores, M. A., and C. Day. 2006. "Contexts Which Shape and Reshape New Teachers' Identities: A Multi-perspective Study." Teaching and Teacher Education 22 (2): 219-232. doi:10.1016/j. tate.2005.09.002.

Flores, M. A., and L. Niklasson. 2014. "Why Do Student Teachers Enrol for A Teaching Degree? A Study of Teacher Recruitment in Portugal and Sweden." Journal of Education for Teaching 40 (4): 328-343. doi:10.1080/02607476.2014.929883.

Glaser, B. G., and A. L. Strauss. 1967. The Discovery of Grounded Theory: Strategies for Qualitative Research. Chicago: Aldine.

Hong, J. Y. 2010. "Pre-service and Beginning Teachers' Professional Identity and Its Relation to Dropping Out of the Profession." Teaching and Teacher Education 26: 1530-1543. doi:10.1016/j. tate.2010.06.003.

Lamote, C., and N. Engels. 2010. "The Development of Student Teachers' Identity." European Journal of Teacher Education 33 (1): 3-18. doi:10.1080/02619760903457735.

Lu, Y., and J. S. Curwood. 2015. "Update Your Status: Exploring Preservice Teacher Identities in an Online Discussion Group." Asia-Pacific Journal of Teacher Education 43 (5): 438-449. doi:10.1080/ 1359866X.2014.960802.

Miles, M., and M. Huberman. 1994. Qualitative Data Analysis. An Expanded Sourcebook. 2nd ed. Thousand Oaks: CA: Sage.

Moreira, M. A., and F. Vieira. 2012. "Preservice Teacher Education in Portugal. The Transformative Power of Local Reform." In Globalism and Power. Iberian Education and Curriculum Policies, edited by J. M. Paraskeva and J. Torres, 94-105. New York: Peter Lang.

Nickel, J., and J. Zimmer. 2018. "Professional Identity in Graduating Teacher Candidates." Teaching Education. doi:10.1080/10476210.2018.1454898.

Pillen, M., D. Beijaard, and P. den Brok. 2013. "Tensions in Beginning Teachers' Professional Identity Development, Accompanying Feelings and Coping Strategies." European Journal of Teacher Education 36 (3): 240-260. doi:10.1080/02619768.2012.696192.

Russell, T., and A. Martin. 2014. "A Importância Da Voz Pedagógica E Da Aprendizagem Produtiva Nos Programas De Formação Inicial De Professores." [The importance of pedagogical voice and productive learning in initial teacher education] In Formação E Desenvolvimento Profissional De Professores: Contributos Internacionais, edited by M. A. Flores, 17-40. Coimbra: Edições Almedina.

Sachs, J. 2001. "Teacher Professional Identity: Competing Discourses, Competing Outcomes." Journal of Education Policy 16 (2): 148-161. doi:10.1080/02680930116819.

Sancho, J. M., J. M. Correa, X. Giró, and L. Fraga. 2014. Aprender a ser docente en un mundo en cambio. Simposio internacional. [Learning to be a teacher in a changung world. International Symposium]. Barcelona: Dipòsit Digital de la Universitat de Barcelona

Schepens, A., A. Aelterman, and P. Vlerick. 2009. "Student Teachers' Professional Identity Formation: Between Being Born as a Teacher and Becoming One." Educational Studies 35 (4): 361-378. doi:10.1080/03055690802648317. 
Smagorinsky, P., L. S. Cook, C. Moore, A. Y. Jackson, and P. G. Fry. 2004. “Tensions in Learning to Teach. Accommodation and the Development of a Teaching Identity." Journal of Teacher Education 55 (1): 8-24. doi:10.1177/0022487103260067.

Sutherland, L., A. Howard, and L. Markauskaite. 2010. "Professional Identity Creation: Examining the Development of Beginning Preservice Teachers' Understanding of Their Work as Teachers." Teaching and Teacher Education 26: 455-465. doi:10.1016/j.tate.2009.06.006.

Thomas, L., and C. Beauchamp. 2007. "Learning to Live Well as Teachers in a Changing World: Insights into Developing a Professional Identity in Teacher Education." Journal of Educational Thought 41 (3): 229-243.

Thomas, L., and C. Beauchamp. 2011. “Understanding New Teachers' Professional Identities through Metaphor." Teaching and Teacher Education 27: 762-769. doi:10.1016/j.tate.2010.12.007.

Timostsuk, I., and A. Ugaste. 2010. "Student Teachers' Professional Identity." Teaching and Teacher Education 26: 1563-1570. doi:10.1016/j.tate.2010.06.008.

Vieira, F., M. A. Flores, J. L. Silva, and J. Almeida, M. A. Flores \& D. Imig, (2018). 2019. “Understanding and Enhancing Change in post-Bologna Pre-service Teacher Education: Lessons from Experience and Research in Portugal." In Leading Change in Teacher Education. Lessons from Countries and Education Leaders around the Globe, edited by T. Al Barwani, 41-57. Milton Park: Routledge.

Yuan, R., and I. Lee. 2016. "I Need to Be Strong and Competent: A Narrative Inquiry of a Studentteacher's Emotions and Identities in Teaching Practicum." Teachers and Teaching Theory and Practice 22 (7): 819-841. doi:10.1080/13540602.2016.1185819.

Zimmermann, P., E. Flavier, and J. Méard. 2012. " $L$ ' identité professionnelle des enseignants en formation initiale Spiral-E." Revue de Recherche en Éducation 49: 35-50. 